Ekonomia - Wroclaw Economic Review 24/3 (2018)

Acta Universitatis Wratislaviensis

No 3881

DOI: 10.19195/2084-4093.24.3.6

Tomasz Waniowski

ORCID: 0000-0002-1678-0668

Uniwersytet Wrocławski

ziemnyturystyczny@wp.pl

Sylwia Żakowska

ORCID: 0000-0002-7856-2076

Uniwersytet Warszawski

zakowska.sylwia@gmail.com

\title{
Dynamika rozwoju biegów masowych w Polsce - analiza statystyczna
}

Artykuł nadesłany: 19 lipca 2018 r.; artykuł zaakceptowany: 10 września 2018 r.

JEL Classification: M31, I12

Keywords: mass-participation run, running events, statistical analysis, chain indexes, single-item indexes, average rate of change

\begin{abstract}
The dynamic of development of mass-participation running events in Poland: Statistical analysis

The quantitative development of mass-participation running events in Poland, especially in recent years, is huge. Nowadays, there are more than 4,000 runs organized every year and they are open for everyone. These running events have a different number of participants (from as little as 10 people, up to even a few thousands) and they are organized in many places by various institutions and organizations. Furthermore, we can distingusih long-distance runs (mainly marathons and half-marathons) and shorter-distance runs (e.g. $10 \mathrm{~km}$ ).

The aim of this of article is to analyze mass-participation running events in Poland statistically, taking into account many criteria: quantity, location, distance and sex. The following statistical methods are used: chain indexes and average annual rate of change. Statistical data were obtained directly from organizers, their websites and different publications about mass-participation running events in Poland. The authors present a versatile statistical view on Polish mass running events in tabular and chart forms.
\end{abstract}




\section{Wstęp}

Rosnąca liczba biegów w wielu krajach na świecie zainspirowała polskie środowiska biegowe do organizacji podobnych przedsięwzięć nie tylko dla osób zajmujących się bieganiem zawodowo, lecz także tych, dla których stanowi to element zdrowego trybu życia. Od początku XXI wieku liczba organizowanych biegów ciągle rośnie, a największy wzrost nastąpił w roku 2005 oraz w latach 2010-2016, zarówno w przypadku liczby organizowanych wydarzeń biegowych, jak i liczby osób biorących w nich udział. Było to związane ze zmianą stylu życia Polaków. Bieganie zaczęło cieszyć się dużą popularnością ze względu na fakt, iż nie wymaga ono dużych nakładów finansowych, zwłaszcza w początkowej fazie biegania amatorskiego. W związku z tak szybkim rozwojem masowych imprez biegowych pojawiło się wiele różnych opracowań dotyczących zarówno aspektów organizacyjnych i marketingowych (Dzięgiel, 2014; Dzięgiel, Lubowiecki-Vikuk, 2013; Szajda, 2014), jak i związanych z kształtowaniem zdrowego stylu życia (Korzewa, Misiołek, Skarbowska, 2014; Murphy, Mackenzie, 2015; Rogers, 2011; Staszak, Staszewski, Żakowska, 2010). Brakuje jednak porównawczych analiz statystycznych, które pozwoliłyby na ilościową analizę biegów. Jedyną naukową analizę statystyczną przeprowadził Z. Waśkowski i to ograniczoną do lat 2011-2013 (Waśkowski, 2014, s. 9-17). Dlatego głównym celem niniejszego artykułu jest analiza biegów masowych w Polsce pod względem zmiany liczby ich uczestników na przestrzeni lat oraz frekwencja w zależności od płci. Analizie poddane zostaną biegi wyróżniające się największą liczbą uczestników w podziale na maratony $(42,195 \mathrm{~km})$, półmaratony $(21,0975 \mathrm{~km})$ oraz biegi na $10 \mathrm{~km}$. Ze szczegółowej analizy biegów na dłuższych i krótszych dystansach oraz mających nietypową liczbę kilometrów zrezygnowano ze względu na ich trudną porównywalność statystyczną.

Dane statystyczne pozyskano bezpośrednio od organizatorów imprez biegowych, z ich stron internetowych oraz firm zajmujących się ewidencją uczestników oraz profesjonalnym pomiarem czasu podczas biegów.

\section{Historia biegania w Polsce}

Początki biegania masowego w Polsce były trudne i przez długi czas nie obserwowano większego zainteresowania tym sportem. Pierwsze ważniejsze wydarzenie miało miejsce w roku 1966, kiedy swoją pierwszą edycję miał najstarszy obecnie polski maraton w niewielkim miasteczku Dębno koło Gorzowa Wielkopolskiego. Bieg upamiętniał tysiąclecie państwa polskiego oraz bitwę pod - niedaleko położoną - Cedynią. Maraton ten stał się imprezą cykliczną, a jego pierwsze edycje gromadziły zaledwie kilkudziesięciu uczestników.

Jedną z najstarszych i zarazem największych imprez biegowych w kraju, Maraton Warszawski, zorganizowano po raz pierwszy w 1979 roku pod nazwą „Maraton Pokoju”. Ciekawym zjawiskiem było olbrzymie jak na tamte czasy za- 
interesowanie imprezą i fakt, iż rok później, w drugiej edycji biegu, udział wzięło 2289 uczestników, więcej niż wówczas brało udział w najsłynniejszych maratonach świata - berlińskim i nowojorskim. Jednak w kolejnych latach uczestników Maratonu Warszawskiego ubywało. Nie obserwowano dużego wzrostu zainteresowania imprezami biegowymi, więc nie organizowano zbyt wielu takiego rodzaju wydarzeń, chociaż cztery lata później, w 1983 roku, odbyła się pierwsza edycja Maratonu Ślężan, obecnego Wrocław Maratonu (www.maratonypolskie.pl).

Prawdziwy przełom nastąpił dopiero w drugiej połowie lat 90 . i na początku XXI wieku. Był to czas rosnącego zainteresowania zdrowym stylem życia, wzrostem zamożności i mobilności społeczeństwa oraz większej otwartości na powstawanie nowych inicjatyw i upowszechnianie się biegania poprzez między innymi organizację imprez biegowych, w których uczestniczyć mógł praktycznie każdy. Wtedy na szerszą skalę zaczęto organizować również biegi na krótszych dystansach niż 42,195 km, a więc bardziej dostępne dla większej liczby uczestników. Nie oznaczało to rezygnacji z organizowania maratonów, gdyż na przykład w 2000 roku odbyła się pierwsza edycja Hansaplast Poznań Maraton. Kolejnym przełomem był rok 2005, w którym liczba organizowanych biegów wzrosła ponad trzykrotnie i od tego roku można mówić o upowszechnieniu się biegania w Polsce w skali masowej. Uczestnicy największych biegów nie byli już liczeni w setkach, lecz w tysiącach. Gwałtownie zaczęły rozwijać się organizacje zrzeszające biegaczy, kluby biegowe i, co bardzo istotne, na popularności zaczęły zyskiwać też inne formy zdrowego stylu życia (fit, wellness). Od roku 2009 do 2016 trwał okres ilościowego rozwoju biegów masowych w Polsce (rysunek 1), szczególnie na krótszych dystansach.

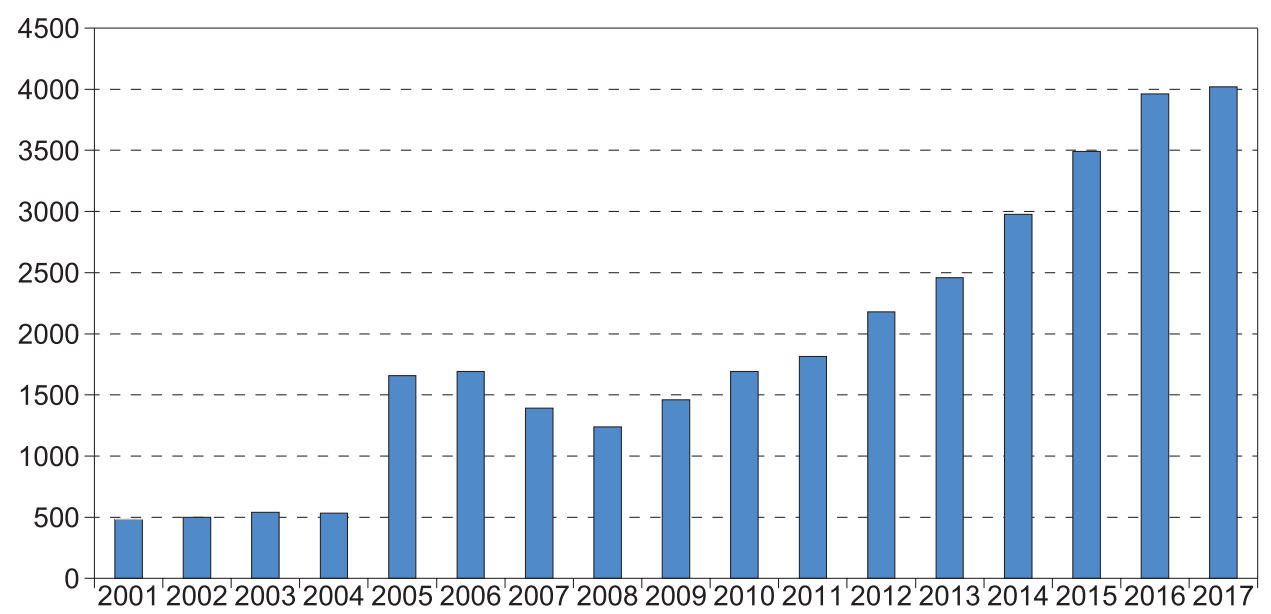

Rysunek 1. Liczba biegów organizowanych w Polsce w latach 2001-2017

Źródło: opracowanie własne na podstawie: www.maratonypolskie.pl, www.enduhub.com.

Największe biegi w kraju przyciągały nie kilka, lecz kilkanaście tysięcy biegaczy. Niemal w każdym dużym i średnim mieście rokrocznie odbywa się półmaraton i co najmniej kilka biegów na różnych dystansach, a na popularności 
zyskują imprezy typu parkrun, a także liczne i nietypowe formy rywalizacji biegowej - runmaggeddon, survival race i inne. Znaczny wzrost zainteresowania obserwowany jest również w wypadku biegów typu ultra i górskich. W ostatnich dwóch latach nastąpiło pewne wyhamowanie dynamicznego dotąd przyrostu. Największe biegi w kraju w dużej mierze notują stabilizację lub nawet nieznaczny spadek liczby uczestników, niemniej w większości mniejszych biegów uczestników przybywa.

Obecnie cechą charakterystyczną imprez biegowych jest dynamiczny rozwój wydarzeń towarzyszących. Coraz bogatsze są pakiety startowe, rośnie liczba sponsorów, a na trasach można zauważyć coraz więcej specjalistycznych urządzeń do pomiaru czasu.

\section{Statystyka maratonów}

Do analizy wybrano dziewięć największych i najbardziej prestiżowych biegów maratońskich, których obecnie organizuje się ponad 100 rocznie, a największe z nich, poza jednym wyjątkiem (Dębno), związane są z największymi polskimi miastami.

Tabela 1. Liczba uczestników wybranych biegów maratońskich w latach 2000-2017

\begin{tabular}{l|l|r|r|r|r|r|r|r|r|r|l}
\hline $\begin{array}{c}\text { Nazwa } \\
\text { biegu }\end{array}$ & Miasto & 2000 & 2005 & 2010 & 2011 & 2012 & 2013 & 2014 & 2015 & 2016 & 2017 \\
\hline $\begin{array}{l}\text { Poznań } \\
\text { Maraton }\end{array}$ & Poznań & 716 & 2061 & 3873 & 4630 & 5425 & 5678 & 6326 & 6251 & 5888 & 6361 \\
\hline $\begin{array}{l}\text { Cracovia } \\
\text { Marathon }\end{array}$ & Kraków & - & 888 & 2420 & 3200 & 3014 & 4415 & 5378 & 4578 & 5548 & 5615 \\
\hline $\begin{array}{l}\text { Orlen } \\
\text { Warsaw } \\
\text { Marathon }\end{array}$ & Warszawa & - & - & - & - & - & 3947 & 5816 & 7361 & 6591 & 5522 \\
\hline $\begin{array}{l}\text { Maraton } \\
\text { Warszawski }\end{array}$ & Warszawa & 587 & 1689 & 3322 & 4061 & 6979 & 8509 & 6675 & 6511 & 5921 & 5466 \\
\hline $\begin{array}{l}\text { Wrocław } \\
\text { Maraton }\end{array}$ & Wrocław & 468 & 900 & 1988 & 2773 & 3896 & 3501 & 3840 & 4757 & 4212 & 4631 \\
\hline $\begin{array}{l}\text { Gdańsk } \\
\text { Maraton }\end{array}$ & Gdańsk & - & - & - & - & - & - & - & 2102 & 1565 & 2377 \\
\hline $\begin{array}{l}\text { Dębno } \\
\text { Maraton }\end{array}$ & Dębno & 806 & 520 & 976 & 806 & 1091 & 1342 & 2074 & 1820 & 2100 & 2180 \\
\hline $\begin{array}{l}\text { Silesia } \\
\text { Maraton }\end{array}$ & Katowice & - & - & - & 695 & 731 & 832 & 1215 & 1204 & 1475 & 1810 \\
\hline $\begin{array}{l}\text { Maraton } \\
\text { Lódź }\end{array}$ & Łódź & - & - & - & 464 & 1010 & 1016 & 1638 & 1169 & 1707 & 1282 \\
\hline
\end{tabular}

Źródło: dane organizatorów poszczególnych biegów: www.lodzmaraton.pl, www.wroclawmaraton.pl, www.marathon.poznan.pl, www.cracoviamaraton.pl, www.debnomaraton.pl, www.silesiamarathon.pl, www.enduhub.com. 
W tabeli 1 przedstawiono liczbę uczestników poszczególnych biegów w latach 2000, 2005 oraz 2010-2017. Warto zauważyć, że dwa największe maratony nie są zlokalizowane w stolicy Polski, którą zamieszkuje największa liczba ludności, lecz w Poznaniu oraz Krakowie. Maratony odbywające się w Warszawie znalazły się na trzecim oraz czwartym miejscu pod względem liczby biegaczy. Pięć z tych maratonów (Warszawski, Poznań, Cracovia, Wrocław i Dębno) swój prestiż dodatkowo buduje przynależnością do tak zwanej Korony Maratonów Polskich, których ukończenie w ciągu dwóch lat daje prawo do uzyskania dodatkowego medalu i umieszczenia na specjalnej liście. W biegach maratońskich wyraźnie jednak widać wyhamowanie tendencji wzrostowej w ostatnich latach. Może to oznaczać, że wyczerpały się możliwości dalszego wzrostu ilościowego biegów, które nie są dostępne dla każdego i wymagają, w przeciwieństwie do krótszych dystansów, bardziej specjalistycznego i dłuższego treningu. Można nawet zauważyć znaczne zmiany liczby uczestników danego biegu w kolejnych latach, szczególnie ostatnich. W ujęciu procentowym przedstawiono to w tabeli 2. Wynika to przede wszystkim z tego, że biegi są często elementem większego wydarzenia związanego z danym miastem i wówczas liczba uczestników rośnie.

Tabela 2. Zmiana procentowa liczba uczestników biegów maratońskich w relacji do roku poprzedniego w latach 2011-2017

\begin{tabular}{l|r|r|r|r|r|r|r}
\hline \multicolumn{1}{c|}{ Nazwa biegu } & $11 / 10$ & $12 / 11$ & $13 / 12$ & $14 / 13$ & $15 / 14$ & $16 / 15$ & $17 / 16$ \\
\hline Gdańsk Maraton & - & - & - & - & - & -26 & 52 \\
\hline Silesia Maraton & - & 5 & 14 & 46 & -1 & 23 & 23 \\
\hline Wrocław Maraton & 39 & 40 & -10 & 10 & 24 & -11 & 10 \\
\hline Poznań Maraton & 20 & 17 & 5 & 11 & -1 & -6 & 8 \\
\hline Dębno Maraton & -17 & 35 & 23 & 55 & -12 & 15 & 4 \\
\hline Cracovia Marathon & 32 & -6 & 46 & 22 & -15 & 21 & 1 \\
\hline Maraton Warszawski & 22 & 72 & 22 & -22 & -2 & -9 & -8 \\
\hline Orlen Warsaw Marathon & - & - & - & 47 & 27 & -10 & -16 \\
\hline Maraton Łódź & - & 118 & 1 & 61 & -29 & 46 & -25 \\
\hline
\end{tabular}

Źródło: opracowanie własne na podstawie: www.lodzmaraton.pl, www.wroclawmaraton.pl, www. marathon.poznan.pl, www.cracoviamaraton.pl, www.debnomaraton.pl, www.silesiamarathon.pl, www.enduhub.com.

Spore znaczenie może mieć też pogoda, gdyż w przypadku wyjątkowo niesprzyjających warunków atmosferycznych niektórzy ze zgłoszonych zawodników rezygnują ze startu (tak było w Maratonie Wrocław w 2016 roku, kiedy mimo połowy września panowała bardzo wysoka temperatura). Najwyższy procentowy spadek odnotowano w przypadku Maratonu Łódź w roku 2015 w stosunku do poprzedniego. Była to zmiana o $29 \%$, co stanowi liczbę blisko 500 uczestników. Spadek ten został jednak odwrócony w przypadku kolejnego roku, kiedy 
liczba uczestników wzrosła w porównaniu do roku poprzedniego o $46 \%$, czyli 538 uczestników. Było to spowodowane intensywną promocją tego biegu, którą podjęli organizatorzy w 2016 roku. W ostatnich latach najwyższy przyrost liczby uczestników odnotowano podczas Maratonu Gdańskiego. Ich procentowy udział wzrósł w 2017 roku względem 2016 o 52\%, co stanowi liczbę 812 osób. Taka tendencja wzrostowa może się utrzymać ze względu na fakt, iż jest to jedyny maraton organizowany w Trójmieście, gdzie są wyjątkowo dobre warunki do treningów biegowych.

W tabeli 3 przedstawiono średnioroczne tempo wzrostu liczby uczestników i można zauważyć, że największym wzrostem w XXI wieku cieszy się Wroclaw Maraton, niewiele mniejszym Maraton Warszawski. W wypadku maratonu w Dębnie średnioroczny wzrost byłyby wyższy, gdyby nie limity wyznaczane przez organizatorów związane z ograniczoną pojemnością trasy w tym małym lubuskim mieście.

Tabela 3. Średnioroczne tempo zmian liczby uczestników biegów maratońskich w latach 2000-2017 (w \%)

\begin{tabular}{l|l|c}
\hline \multicolumn{1}{c|}{ Nazwa biegu } & \multicolumn{1}{c|}{ Miasto } & Średnioroczne tempo zmian \\
\hline Wrocław Maraton & Wrocław & 29 \\
\hline Maraton Warszawski & Warszawa & 28 \\
\hline Poznań Maraton & Poznań & 27 \\
\hline Cracovia Maraton & Kraków & 26 \\
\hline Maraton Łódź & Łódź & 18 \\
\hline Silesia Maraton & Katowice & 17 \\
\hline Dębno Maraton & Dębno & 12 \\
\hline Orlen Warsaw Marathon & Warszawa & 9 \\
\hline Gdańsk Maraton & Gdańsk & 6 \\
\hline
\end{tabular}

Źródło: opracowanie własne na podstawie: www.lodzmaraton.pl, www.wroclawmaraton.pl, www. marathon.poznan.pl, www.cracoviamaraton.pl, www.debnomaraton.pl, www.silesiamarathon.pl, www.enduhub.com.

Najniższe tempo zmian wystąpiło w przypadku Gdańsk Maratonu, prawdopodobnie ze względu na fakt, iż jest on organizowany najkrócej, bo dopiero od 2014 roku.

Powszechnie wiadomo, że kobiety biegają rzadziej od mężczyzn, a więc kobiet uczestniczących w zawodach jest znacznie mniej. Wiele statystyk biegowych ukazuje różnice w zachowaniu w zależności od płci. W tabeli 4 ukazane zostały średnioroczne tempa zmian liczby kobiet i mężczyzn uczestniczących w biegach maratońskich w latach 2012-2017. 
Tabela 4. Średnioroczne tempo zmian liczby kobiet i mężczyzn uczestniczących w biegach maratońskich w latach 2012-2017 (w \%)

\begin{tabular}{l|l|c|c}
\hline \multicolumn{1}{c|}{ Nazwa biegu } & Miasto & $\begin{array}{c}\text { Średnie tempo zmian } \\
\text { liczby kobiet }\end{array}$ & $\begin{array}{c}\text { Średnie tempo zmian } \\
\text { liczby mężczyzn }\end{array}$ \\
\hline Dębno Maraton & Dębno & 30 & 13 \\
\hline Cracovia Marathon & Kraków & 28 & 11 \\
\hline Silesia Marathon & Katowice & 26 & 19 \\
\hline Orlen Warsaw Marathon & Warszawa & 24 & 13 \\
\hline Gdańsk Maraton & Gdańsk & 22 & 2 \\
\hline Wrocław Maraton & Wrocław & 14 & 2 \\
\hline Poznań Maraton & Poznań & 14 & 4 \\
\hline Łódź Maraton & Łódź & 13 & -6 \\
\hline Maraton Warszawski & Warszawa & 6 &
\end{tabular}

Źródło: opracowanie własne na podstawie: www.lodzmaraton.pl, www.wroclawmaraton.pl, www. marathon.poznan.pl, www.cracoviamaraton.pl, www.debnomaraton.pl, www.silesiamarathon.pl, www.enduhub.com.

Wynika z niej, że przyrost liczby kobiet jest we wszystkich biegach znacznie wyższy niż przyrost liczby mężczyzn. Kobiety bowiem nieco później zainteresowały się bieganiem oraz poważniej traktują treningi przed tak wymagającym dystansem, jakim jest bieg maratoński. Najwyższą roczną zmienność liczby uczestniczących w nim kobiet na przestrzeni analizowanych lat zanotowano w Dębnie, Krakowie i Katowicach. Warto zauważyć, iż liczba kobiet z roku na rok rośnie w wypadku każdego z analizowanych maratonów, co świadczy o wzroście ich aktywności oraz coraz większym zainteresowaniu tego typu sportem. W przypadku mężczyzn poziom zmienności był zdecydowanie niższy, a najwyższą wartość uzyskał w wypadku Silesii Marathonu (19\%). W jednym z biegów, Maratonie Warszawskim, liczba uczestniczących mężczyzn nawet spadła (o 6\%), ponieważ w 2013 roku pojawił się konkurencyjny Orlen Warsaw Marathon. Maraton Warszawski odbywa się w mniej dogodnym terminie, pod koniec września, czyli w okresie największego nasycenia sezonu biegowego. Natomiast Orlen Warsaw Marathon ma miejsce w drugiej połowie kwietnia, kiedy biegów jest znacznie mniej. Gwałtowny spadek ogólnej liczby uczestników Maratonu Warszawskiego w 2013 roku widoczny jest na rysunku 2, na którym przedstawiono liczbę uczestników czterech maratonów z najdłuższa tradycją. 


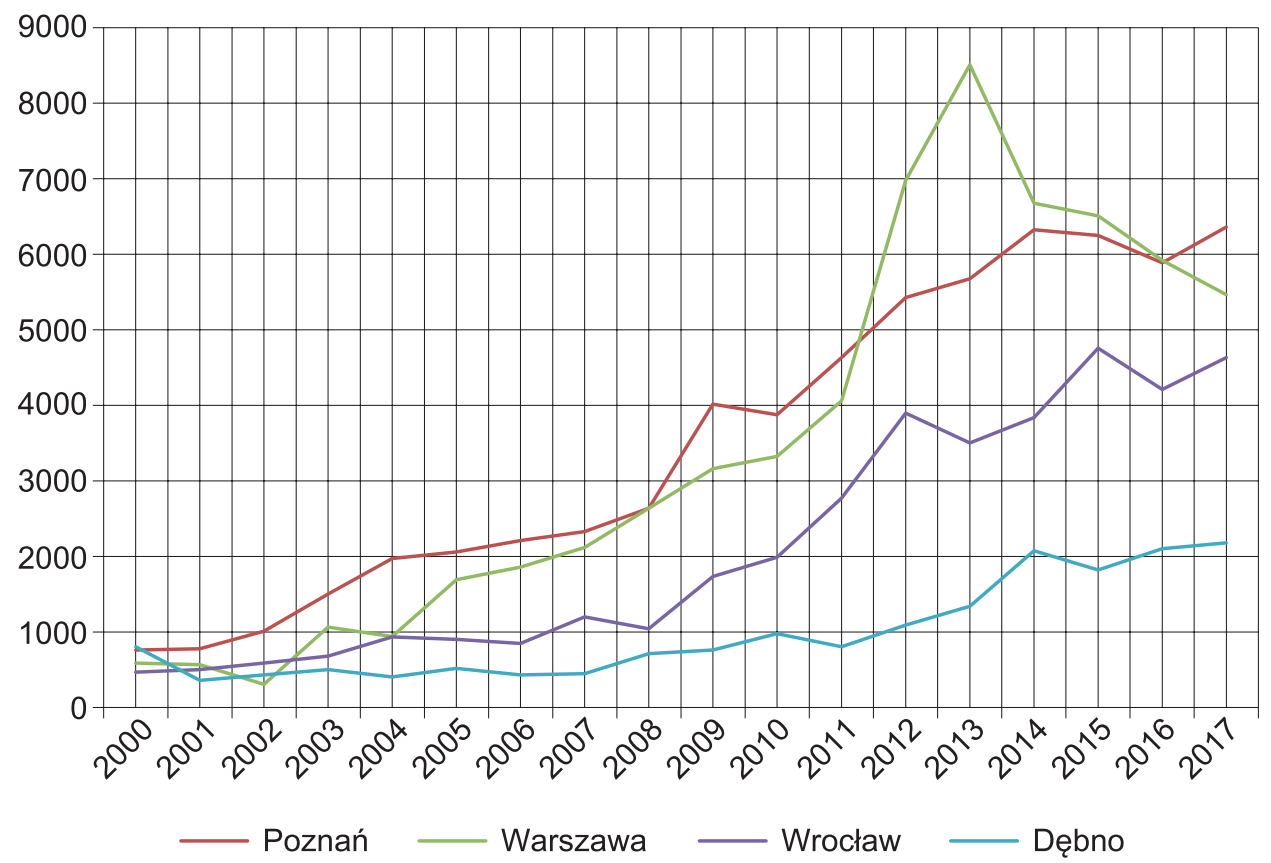

Rysunek 2. Liczba uczestników czterech najstarszych maratonów polskich w latach 2000-20171

Źródło: opracowanie własne na podstawie: www.marathon.poznan.pl, www.pzumaratonwarszawski.com, www.wroclawmaraton.pl, www.debnomaraton.pl.

Sytuacja Maratonu Warszawskiego jest symptomatyczna ze względu na to, że w dwóch poprzednich latach odnotował on największy wzrost liczby biegaczy. Ten przykład oraz sytuacja pozostałych biegów przedstawionych na rysunku 2 pokazuje, że mimo ogólnej tendencji wzrostowej w krótkich okresach liczba uczestników może się zmniejszać.

\section{Półmaratony}

Biegów na dystansie 21,0975 m jest zdecydowanie więcej niż maratonów ze względu na dostępność dla zdecydowanie większej liczby biegaczy - aktualnie jest ich około 500 rocznie. Większość z nich zaczęła być rozgrywana w roku 2005 lub później, stąd też niektóre z największych półmaratonów mają stosunkowo krótką historię, choć istnieją biegi na tym dystansie organizowane corocznie od ponad 25 lat (na przykład Półmaraton Żywiecki od 1991 roku). Było to związane z ich szybko rosnącą popularnością wynikającą między innymi z intensywnego ich promowania szczególnie w latach 2013-2014. Liczbę uczestników największych polskich półmaratonów przedstawiono w tabeli 5 .

${ }^{1}$ Dla Wrocław Maratonu oraz Dębno Maratonu dane dla roku 2002 zostały uśrednione z 2001 i 2003 roku, ze względu na brak udostępnionych danych statystycznych. 
Tabela 5. Liczba uczestników wybranych półmaratonów w latach 2010-2017

\begin{tabular}{l|l|c|c|c|c|c|c|c|c}
\hline $\begin{array}{c}\text { Nazwa } \\
\text { biegu }\end{array}$ & \multicolumn{1}{|c|}{ Miasto } & 2010 & 2011 & 2012 & 2013 & 2014 & 2015 & 2016 & 2017 \\
\hline $\begin{array}{l}\text { Półmaraton } \\
\text { Warszawski }\end{array}$ & Warszawa & 3528 & 4700 & 7174 & 10077 & 11156 & 12957 & 12735 & 12186 \\
\hline $\begin{array}{l}\text { Półmaraton } \\
\text { Poznań }\end{array}$ & Poznań & 2471 & 3517 & 4409 & 5747 & 6655 & 8048 & 11347 & 10398 \\
\hline $\begin{array}{l}\text { Nocny } \\
\text { Półmaraton }\end{array}$ & Wrocław & - & - & - & - & 4972 & 6962 & 9357 & 9894 \\
\hline $\begin{array}{l}\text { Cracovia } \\
\text { Półmaraton }\end{array}$ & Kraków & - & - & - & - & 3744 & 5837 & 7080 & 8332 \\
\hline $\begin{array}{l}\text { Półmaraton } \\
\text { Praski }\end{array}$ & Warszawa & - & - & - & - & 5934 & 5865 & 5646 & 7350 \\
\hline $\begin{array}{l}\text { Półmaraton } \\
\text { Ślężański }\end{array}$ & Sobótka & 966 & 1201 & 2953 & 2659 & 3281 & 3778 & 4417 & 3754 \\
\hline $\begin{array}{l}\text { Półmaraton } \\
\text { Gdańsk }\end{array}$ & Gdańsk & - & - & - & - & 1981 & 3259 & 3218 & 3678 \\
\hline $\begin{array}{l}\text { Półmaraton } \\
\text { Philipsa }\end{array}$ & Piła & 1721 & 2114 & 1933 & 2431 & 2856 & 3092 & 3259 & 3624 \\
\hline $\begin{array}{l}\text { Półmaraton } \\
\text { Marzanny }\end{array}$ & Kraków & 463 & 415 & 1175 & 1699 & 2461 & 3247 & 2877 & 3179 \\
\hline $\begin{array}{l}\text { Silesia } \\
\text { Półmaraton }\end{array}$ & Katowice & - & 1054 & 395 & 829 & 748 & 1134 & 1749 & 2895 \\
\hline $\begin{array}{l}\text { Półmaraton } \\
\text { Słowaka }\end{array}$ & $\begin{array}{l}\text { Grodzisk } \\
\text { Wielko- } \\
\text { polski }\end{array}$ & 897 & 1698 & 2060 & 2035 & 2163 & 2204 & 2367 & 2684 \\
\hline $\begin{array}{l}\text { Półmarámaton } \\
\text { Półmaraton } \\
\text { Szczecin }\end{array}$ & Białystok & - & - & - & 603 & 938 & 1294 & 1686 & 2634 \\
\hline $\begin{array}{l}\text { Półmaraton } \\
\text { Żywiecki }\end{array}$ & Żywiec & 716 & 700 & 848 & 1176 & 1455 & 1850 & 2244 & 1725 \\
\hline
\end{tabular}

Źródło: opracowanie własne na podstawie: www.maratonypolskie.pl, www.enduhub.com.

Liczba uczestników zbliża się lub nawet przekracza 10 tys., a chętnych może być znacznie więcej niż wyznaczone ze względów organizacyjnych limity, stąd też na podstawie analizy tabeli 5 nie powinno się wyciągać wniosków o wyczerpywaniu się formuły tego typu biegów (skoro na przykład liczba uczestników Półmaratonu Warszawskiego, a ostatnio również Poznańskiego spada). Przykładem może być Nocny Wrocław Półmaraton, odbywający się w połowie czerwca, a zapisy uruchamiane są 1 stycznia. W roku 2017 limit wyznaczony przez organizatorów (10 tys.) został wypełniony 6 lutego, a w roku 2018 (powiększony do 11 tys.) — już w połowie stycznia. Jego popularność wynika też z tego, że jest to jedyny nocny półmaraton, rozpoczynający się o godzinie 22.00. Większość biegów, w których liczba uczestników jest wyraźnie niższa od maksymalnej dopusz- 
czalnej ze względów organizacyjnych, wykazuje zdecydowanie tendencję wzrostową. Szczególny potencjał ma Białystok Półmaraton, który jest największym tego typu biegiem na ścianie wschodniej.

W tabeli 6 zaprezentowano procentowe zmiany liczby uczestników największych polskich półmaratonów.

Tabela 6. Indeksy łańcuchowe liczby uczestników półmaratonów w relacji do roku poprzedniego w latach 2010-2017 (w \%)

\begin{tabular}{|c|c|c|c|c|c|c|c|c|}
\hline Nazwa biegu & Miasto & $\begin{array}{l}2011 / \\
2010 \\
\end{array}$ & $\begin{array}{l}2012 / \\
2011\end{array}$ & $\begin{array}{l}2013 / \\
2012\end{array}$ & $\begin{array}{l}2014 / \\
2013 \\
\end{array}$ & $\begin{array}{l}2015 / \\
2014\end{array}$ & $\begin{array}{l}2016 / \\
2015\end{array}$ & $\begin{array}{l}2017 / \\
2016\end{array}$ \\
\hline Silesia Półmaraton & Katowice & - & -63 & 110 & -10 & 52 & 54 & 66 \\
\hline Białystok Półmaraton & Białystok & - & - & - & 56 & 38 & 30 & 56 \\
\hline Półmaraton Praski & Warszawa & - & 一 & - & 一 & -1 & -4 & 30 \\
\hline Cracovia Półmaraton & Kraków & - & - & - & - & 56 & 21 & 18 \\
\hline Półmaraton Gdańsk & Gdańsk & - & - & - & - & 65 & -1 & 14 \\
\hline Półmaraton Słowaka & $\begin{array}{l}\text { Grodzisk } \\
\text { Wielkopolski }\end{array}$ & 89 & 21 & -1 & 6 & 2 & 7 & 13 \\
\hline Półmaraton Philipsa & Piła & 23 & -9 & 26 & 17 & 8 & 5 & 11 \\
\hline Półmaraton Marzanny & Kraków & -10 & 183 & 45 & 45 & 32 & -11 & 10 \\
\hline Nocny Półmaraton & Wrocław & - & - & - & - & 40 & 34 & 6 \\
\hline Półmaraton Szczecin & Szczecin & 35 & 9 & 57 & 15 & 35 & 0 & 4 \\
\hline Półmaraton Warszawski & Warszawa & 33 & 53 & 40 & 11 & 16 & -2 & -4 \\
\hline Półmaraton Poznań & Poznań & 42 & 25 & 30 & 16 & 21 & 41 & -8 \\
\hline Półmaraton Ślężański & Sobótka & 24 & 146 & -10 & 23 & 15 & 17 & -15 \\
\hline Półmaraton Żywiecki & Żywiec & -2 & 21 & 39 & 24 & 27 & 21 & -23 \\
\hline
\end{tabular}

Źródło: opracowanie własne na podstawie: www.maratonypolskie.pl, www.enduhub.com.

Skala niektórych zmian była ogromna, znacznie przekraczająca 100\%. Wskazuje to na ogromne znaczenie kampanii reklamujących dany bieg przy aktywnym udziale potężnych sponsorów. W niektórych wypadkach znaczenie miała też zawartość pakietów startowych oraz umiejętne wkomponowanie samego biegu $\mathrm{w}$ ciąg imprez sportowo-rekreacyjnych $\mathrm{w}$ danym mieście. Jednak jak wynika $\mathrm{z}$ tabeli 6 wzrosty te nie miały na ogół charakteru trwałego i po roku spektakularnego zwiększenia się liczby biegaczy w kolejnej edycji następował spadek. Tak było w przypadku Półmaratonu Ślężańskiego w latach 2012 i 2013 czy też Silesia Półmaratonu w latach 2013 i 2014. Nie zawsze jednak tak było, bo w Półmaratonie Marzanny w Krakowie po ogromnym przyroście liczby uczestników w 2012 roku w trzech kolejnych latach udało się utrzymać dodatnie wskaźniki zmiany liczby uczestników, chociaż na mniejszą skalę niż w roku 2012. W Silesia Półmaratonie, po ponad dwukrotnym wzroście w 2013 roku, w kolejnym nastąpił nieznaczny spadek, a w następnych latach znaczne wzrosty. Przykłady te pokazują, że działa- 
nia marketingowe mające na celu zachęcanie biegaczy do udziału w danym biegu, w warunkach stale rosnącej konkurencji, mogą być skuteczne również w dłuższym okresie. Konkurencja ta nie jest jednak taka sama dla wszystkich biegów, decydują na przykład względy geograficzne, gdyż skoro każde większe miasto ma ambicje organizacji swojego biegu (najczęściej półmaratonu), to znaczenie ma odległość miejscowości, w której odbywa się nowy bieg w stosunku do starego. Dlatego też biegi z długą tradycją, takie jak Półmaraton Słowaka czy też Półmaraton Philipsa, nie notują już tak znacznych zmian w liczbie uczestników, gdyż powstaje dużo innych tego typu imprez w bliskiej okolicy. Rosnącą konkurencją dla Półmaratonu Ślężańskiego w ostatnich latach są masowo organizowane biegi górskie w pobliskich Sudetach, jak chociażby Półmaraton Sowiogórski.

Wyjątkowo interesująca wydaje się analiza średniorocznego tempa zmian kobiet i mężczyzn uczestniczących w półmaratonach w ostatnich latach (tabela 7).

Tabela 7. Średnioroczne tempo zmian liczby kobiet i mężczyzn uczestniczących w największych półmaratonach w latach 2012-2017 (w \%)

\begin{tabular}{|c|c|c|c|}
\hline Nazwa biegu & Miasto & $\begin{array}{l}\text { Średnie tempo zmian } \\
\text { liczby kobiet }\end{array}$ & $\begin{array}{l}\text { Średnie tempo zmian } \\
\text { liczby mężczyzn }\end{array}$ \\
\hline Półmaraton Szczecin & Szczecin & 71 & -6 \\
\hline Białystok Półmaraton & Białystok & 65 & 39 \\
\hline Silesia Półmaraton & Katowice & 53 & 48 \\
\hline Cracovia Półmaraton & Kraków & 40 & 27 \\
\hline Półmaraton Marzanny & Kraków & 37 & 19 \\
\hline Nocny Półmaraton & Wrocław & 37 & 22 \\
\hline Półmaraton Gdańsk & Gdańsk & 32 & 20 \\
\hline Półmaraton Poznań & Poznań & 31 & 16 \\
\hline Półmaraton Philipsa & Piła & 31 & 10 \\
\hline Półmaraton Żywiecki & Żywiec & 29 & 13 \\
\hline Półmaraton Warszawski & Warszawa & 23 & 8 \\
\hline Półmaraton Ślężański & Sobótka & 20 & 3 \\
\hline Półmaraton Słowaka & $\begin{array}{l}\text { Grodzisk } \\
\text { Wielkopolski }\end{array}$ & 16 & 3 \\
\hline Półmaraton Praski & Warszawa & 13 & 6 \\
\hline
\end{tabular}

Źródło: opracowanie własne na podstawie: www.maratonypolskie.pl, www.enduhub.com.

Podobnie jak w biegach maratońskich tempo przyrostu liczby kobiet jest znacznie większe. O ile jednak w maratonach proporcje były bardziej stonowane, w wypadku półmaratonów mamy sytuację Półmaratonu Szczecińskiego, w którym w latach 2012-2017 liczba kobiet rosła w każdym roku średnio o 71\%, liczba mężczyzn spadała o $6 \%$. Świadczy to o udanej próbie działań promocyjnych adresowanych do kobiet. 


\section{Biegi na 10 kilometrów}

Organizacja biegów na $10 \mathrm{~km}$ jest znacznie łatwiejsza od maratonów i półmaratonów. Mogą one odbywać się nie tylko na ulicach miast, lecz także w parkach, na drogach gruntowych czy też na wałach nad rzekami. Cechą charakterystyczną jest organizacja dużej liczby tych biegów przy okazji licznych świąt, rocznic, upamiętniania wydarzeń historycznych i innych. Znacznie częściej niż w przypadku maratonów czy półmaratonów biegi te są imprezami towarzyszącymi przy organizowaniu innych wydarzeń, nie tylko biegowych. Niektóre z nich nie są imprezami cyklicznymi lub mogą być zorganizowane tylko w danym roku (na przykład upamiętnienie okrągłej rocznicy jakiegoś wydarzenia historycznego). Obecnie w skali roku organizowanych jest ponad tysiąc takich imprez. Największe z nich pod względem liczby uczestników przedstawiono w tabeli 8 . Dane zostały uszeregowane na podstawie liczby uczestników biegów w ostatnim analizowanym roku.

Można zauważyć, że najwięcej uczestników odnotowano w Biegu Niepodległości w Warszawie, choć limit założony przez organizatorów w liczbie 18 tys. uczestników nie został wyczerpany. Było to wynikiem terminu jego odbywania, 11 listopada, kiedy część biegaczy, również amatorów, rozpoczyna już tak zwany okres roztrenowania i nie startuje w zawodach. W analizowanych latach bieg ten przewyższał liczbą uczestników wszystkie pozostałe polskie biegi masowe. Dodatkowo warto zwrócić uwagę, że w 2018 roku limit ten został zwiększony do 25 tys. uczestników ze względu na obchody Stulecia Odzyskania Niepodległości. Żeby mieć szanse wypełnienia tego limitu i zachęcenia, mimo niesprzyjającej pory, większej liczby zawodników, bieg ten został wpisany jako element oficjalnych obchodów Narodowego Święta Niepodległości w 2018 roku. Drugie miejsce pod względem liczby uczestników również zajmuje bieg organizowany w Warszawie. Nosi on nazwę Orlen Warsaw Półmarathon, chociaż jest on biegiem towarzyszącym odbywającemu się w tym samym dniu maratonowi, cieszy się dużą popularnością. Warto zauważyć, że aż cztery z pięciu największych polskich „dziesiątek” odbywają się w stolicy. W czołowej dwunastce znalazły się również aż cztery biegi organizowane w Gdyni.

W tabeli 9 przedstawiona została procentowa dynamika poszczególnych biegów. Wyraźnie widać, że większość z dwunastu biegów największych polskich biegów na $10 \mathrm{~km}$ charakteryzuje się znaczną zmiennością, choć dużo częściej zdarzają się spektakularne wzrosty liczby uczestników, dochodzące nawet do $200 \%$, niż ich spadki. 


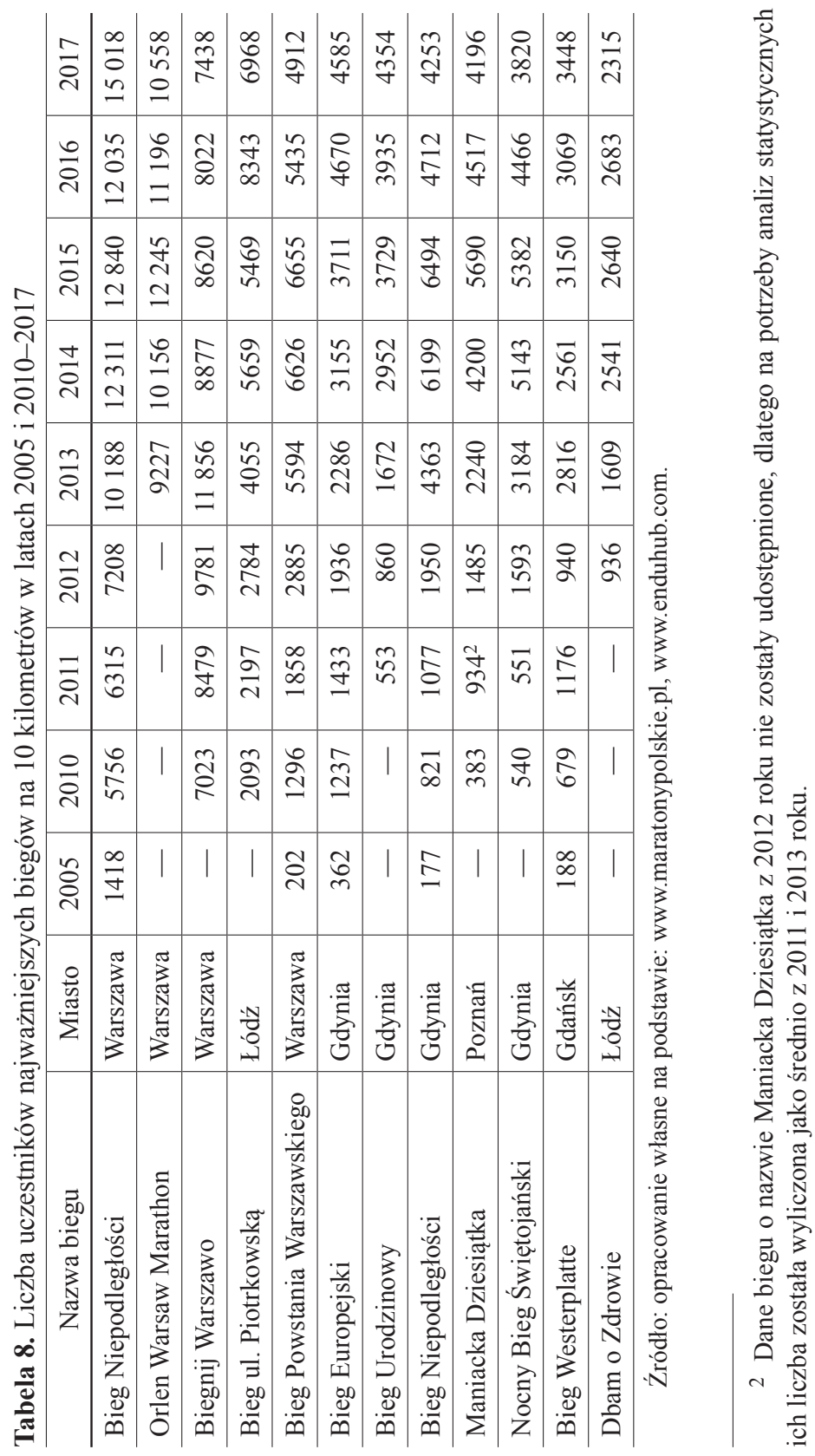


Tabela 9. Zmiana procentowa liczby uczestników biegów na 10 kilometrów w relacji do roku poprzedniego w latach 2010-2017

\begin{tabular}{l|l|r|r|r|r|r|r|c}
\hline \multicolumn{1}{c|}{ Nazwa biegu } & Miasto & $\begin{array}{r}2011 / \\
2010\end{array}$ & $\begin{array}{r}2012 / \\
2011\end{array}$ & $\begin{array}{r}2013 / \\
2012\end{array}$ & $\begin{array}{r}2014 / \\
2013\end{array}$ & $\begin{array}{r}2015 \\
2014\end{array}$ & $\begin{array}{r}2016 / \\
2015\end{array}$ & $\begin{array}{c}2017 / \\
2016\end{array}$ \\
\hline Bieg Niepodległości & Warszawa & 10 & 14 & 41 & 21 & 4 & -6 & 25 \\
\hline Bieg Westerplatte & Gdańsk & 73 & -20 & 200 & -9 & 23 & -3 & 12 \\
\hline Bieg Urodzinowy & Gdynia & - & 56 & 94 & 77 & 26 & 6 & 11 \\
\hline Bieg Europejski & Gdynia & 16 & 35 & 18 & 38 & 18 & 26 & -2 \\
\hline Orlen Warsaw Marathon & Warszawa & - & - & - & 10 & 21 & -9 & -6 \\
\hline Maniacka Dziesiątka & Poznań & 144 & 59 & 51 & 88 & 35 & -21 & -7 \\
\hline Biegnij Warszawo & Warszawa & 21 & 15 & 21 & -25 & -3 & -7 & -7 \\
\hline $\begin{array}{l}\text { Bieg Powstania } \\
\text { Warszawskiego }\end{array}$ & Warszawa & 43 & 55 & 94 & 18 & 0 & -18 & -10 \\
\hline Bieg Niepodległości & Gdynia & 31 & 81 & 124 & 42 & 5 & -27 & -10 \\
\hline Dbam o Zdrowie & Lódź & - & - & 72 & 58 & 4 & 2 & -14 \\
\hline $\begin{array}{l}\text { Nocny Bieg } \\
\text { Świętojański }\end{array}$ & Gdynia & 2 & 189 & 100 & 62 & 5 & -17 & -14 \\
\hline Bieg ul. Piotrkowską & Lódź & 5 & 27 & 46 & 40 & -3 & 53 & -16 \\
\hline
\end{tabular}

Źródło: opracowanie własne na podstawie: www.maratonypolskie.pl, www.enduhub.com.

Analizując dane zawarte w tabeli 9, można jednak zauważyć nieznaczne, lecz wyraźne spadki liczby uczestników w ostatnich latach w największych biegach na 10 kilometrów. Największe odnotowano - w czterech kolejnych latach - w wypadku biegu „Biegnij Warszawo” w sumie o prawie 4,5 tys. uczestników. Może to być spowodowane przesyceniem liczby wydarzeń biegowych organizowanych w Warszawie, tym bardziej że liczne „dziesiątki”, których w Warszawie i w okolicach było ostatnio szczególnie dużo, są organizowane jednorazowo jako elementy ważnych wydarzeń rocznicowych i nie mają charakteru cyklicznego. Przyciągają jednak biegaczy, którzy poszukują odmiany i chętniej będą uczestniczyć w biegu okazjonalnym niż cyklicznym.

W tabeli 10 przedstawiono średnioroczne tempo zmian ze względu na płeć. Podobnie jak w biegach maratońskich i półmaratońskich przyrost kobiet uczestniczących w biegach jest znacznie wyższy w porównaniu z mężczyznami.

Tabela 10. Średnioroczne tempo zmian liczby kobiet i mężczyzn uczestniczących w biegach na $10 \mathrm{~km}$ w latach 2005-2017 (w \%)

\begin{tabular}{l|l|c|c}
\hline \multicolumn{1}{c|}{ Nazwa biegu } & Miasto & $\begin{array}{c}\text { Średnie tempo zmian } \\
\text { liczby kobiet }\end{array}$ & $\begin{array}{c}\text { Średnie tempo zmian } \\
\text { liczby mężczyzn }\end{array}$ \\
\hline Bieg Urodzinowy & Gdynia & 63 & 36 \\
\hline Maniacka Dziesiątka & Poznań & 61 & 33 \\
\hline Bieg ul. Piotrkowską & Łódź & 60 & 36 \\
\hline
\end{tabular}




\begin{tabular}{l|l|c|c}
\hline Bieg Westerplatte & Gdańsk & 56 & 40 \\
\hline Bieg Europejski & Gdynia & 52 & 27 \\
\hline Bieg Niepodległości & Warszawa & 48 & 31 \\
\hline Bieg Niepodległości & Gdynia & 33 & 17 \\
\hline Bieg Powstania Warszawskiego & Warszawa & 32 & 17 \\
\hline Dbam o Zdrowie & Łódź & 27 & 0 \\
\hline Orlen Warsaw Marathon & Warszawa & 10 & -5 \\
\hline Biegnij Warszawo & Warszawa & 4 & -2 \\
\hline Nocny Bieg Świętojański & Gdynia & 3 & .
\end{tabular}

Źródło: opracowanie własne na podstawie: www.maratonypolskie.pl, www.enduhub.com.

Najwyższą średnioroczną zmiennością w wypadku liczby kobiet uczestniczących w biegach na 10 kilometrów charakteryzował się organizowany w Gdyni Bieg Urodzinowy. Nieznacznie niższą zmienność miał Bieg Maniacka Dziesiątka organizowany w Poznaniu. Najbardziej stabilna była liczba uczestniczek podczas biegów Biegnij Warszawo oraz Nocnego Biegu Świętojańskiego w Gdyni. W przypadku mężczyzn największą zmianą cechował się Bieg Westerplatte w Gdańsku, a dwa biegi: Biegnij Warszawo oraz Nocny Bieg Świętojański w latach 2005-2017 zanotowały spadek liczby uczestniczących mężczyzn.

\section{Podsumowanie}

Analizując dynamikę zmian uczestników maratonów, można stwierdzić, że w latach 2011-2014 odnotowano najszybszy ich wzrost. W kolejnych latach była to stabilizacja. Liczba uczestników w ostatnich trzech latach nie zmieniała się już tak dynamicznie poza Gdańsk Maratonem, w którym w 2017 roku wzrosła ona o ponad połowę w relacji do roku poprzedniego. Można zaobserwować również znacznie szybszy wzrost liczby kobiet uczestniczących w biegach maratońskich. Niekiedy przewyższa ona dwukrotnie dynamikę wzrostu liczby mężczyzn uczestniczących w maratonach (szczególnie w Dębno i Cracovia maratonach).

W przypadku liczby uczestników półmaratonów nie można stwierdzić jednoznacznej tendencji. Można uznać, iż w analizowanych latach była bardzo zróżnicowana. Największe średnioroczne wzrosty odnotowano w wypadku Półmaratonu Marzanny, Półmaratonu Ślężańskiego oraz Silesia Półmaratonu. Były to zmiany ponad stuprocentowe w relacji do roku poprzedniego. Ciekawym zjawiskiem jest, podobnie jak w maratonach, zdecydowanie szybszy wzrost liczby kobiet. Tak było szczególnie podczas Szczecin Półmaratonu.

Ostatnie z analizowanych biegów miały dystans $10 \mathrm{~km}$. W tym wypadku najwyraźniej widać dynamikę zmian liczby uczestników. Nie ma ona jednak wyłącznie charakteru wzrostowego. Odnotowano bowiem biegi, w których liczba uczestników znacznie malała w ciągu kilku lat. 
Biegi masowe stanowią pewien całościowy system, w którym udział w jednym biegu ogranicza możliwości uczestnictwa w innym rozgrywanym w tym samym czasie. Zawodnicy, decydując się na dany bieg, kierują się jego prestiżem i długością dystansu, a także specyfiką trasy, zawartością pakietu startowego oraz dodatkowymi atrakcjami towarzyszącymi samemu biegowi. Dlatego też w przyszłości można podjąć próbę skorelowania wyników analizy statystycznej z wymienionymi czynnikami o charakterze jakościowym.

\section{Bibliografia}

Dzięgiel A. (2014), Rynek biegowy w Polsce, [w:] Marketing imprez biegowych, red. Z. Waśkowski, Poznań, s. 141-156.

Dzięgiel A., Lubowiecki-Vikuk A.P. (2013), Imprezy biegowe jako specyficzny rodzaj wydarzeń sportowych, „Zeszyty Naukowe. Turystyka i Rekreacja” 2(12).

Korzewa L., Misiołek E., Skarbowska A. (2014), Turystyka biegowa w Polsce wedlug opinii uczestników biegów masowych, Wrocław.

Murphy T.J., Mackenzie B. (2015), Biegacz niezłomny, Łódź.

Rogers T. (2011), Mój pierwszy maraton, Warszawa.

Rynek biegowy w Polsce, red. Z. Waśkowski (2014), Poznań, s. 9-17.

Staszak K., Staszewski W., Żakowska M. (2010), Biegaj z nami, Warszawa.

Szajda T. (2014), Biznesplan organizacji imprezy biegowej, [w:] Marketing imprez biegowych, red. Z. Waśkowski, Poznań, s. 53-65.

\section{Źródła internetowe}

www.bieganie.pl (dostęp: 10.06.2018).

www.cracoviamaraton.pl (dostęp: 5.06.2018).

www.debnomaraton.pl (dostęp: 5.06.2018).

www.enduhub.com (dostęp: 25.06.2018).

www.lodzmaraton.pl (dostęp: 3.06.2018).

www.magazynbieganie.pl (dostęp: 1.06.2018).

www.magazynbieganie.pl/obozy-biegowe-maja-sens (dostęp: 25.06.2018).

www.marathon.poznan.pl (dostęp: 5.06.2018).

www.maratony24.pl/bieganie/historia_maratonu,1361.html (dostęp: 25.06.2018).

www.maratonypolskie.pl (dostęp: 15.06.2018).

www.psb-biegi.com.pl (dostęp: 14.06.2018).

www.pzumaratonwarszawski.com (dostęp: 5.06.2018).

www.runners-world.pl (dostęp: 10.06.2018).

www.silesiamarathon.pl (dostęp: 6.06.2018).

www.wroclawmaraton.pl (dostęp: 5.06.2018).

Ekonomia - Wroclaw Economic Review 24/3 (2018)

(C) for this edition by CNS 